$\begin{array}{lllllll}R & E & S & \text { E } & N & H & \text { A }\end{array}$

\section{EXPERIÊNCIAS DE ORÇAMENTO PARTICIPATIVO NO BRASIL - PERÍODO DE 1997 A 2000}

Ana Clara Torres Ribeiro

Grazia de Grazia

Petrópolis: Fórum Nacional de Participação Popular/ Editora Vozes, 2003.

\section{Rosa Maria Cortês de Lima (UfPE)}

Fruto de uma pesquisa de âmbito nacional, o instigante trabalho realizado no universo dos municípios brasileiros com experiência em Orçamento Participativo é entregue ao público: Experiências de Orçamento Participativo no Brasil: 1997-2000. O livro responde a uma demanda enraizada no Fórum Nacional de Participação Popular (FNPP), e oriunda de um conjunto de discussões empreendidas entre diversas entidades vinculadas às causas populares. Nasce como um trabalho pioneiro que torna possível a discussão da totalidade das experiências em curso, no período definido, preenchendo lacunas existentes no tratamento de práticas localizadas.

Situado no interior das mudanças das relações entre Estado e sociedade no Brasil, o Orçamento Participativo aponta para "experiências portadoras da esperança de uma democracia concreta, de uma cidadania vivida e do desvendamento de caminhos para a redução das desigualdades sociais" (p.17). Seus pilares tiveram sustentação nas reivindicações de movimentos populares no confronto com os limites da democracia representativa no País.

Norteou a pesquisa a convicção de que o Orçamento Participativo configura-se pelo fato de a gestão pública ter seus tentáculos fincados na participação direta da população e/ou por intermédio da representação organizada (entidades) em distintos momentos $\mathrm{da}$ elaboração e execução do orçamento. "É, portanto, o teor e a dimensão da participação que indicam se o orçamento está sendo efetivamente co-gerido" (p.19). Desafios metodológicos, em face do desenho da pesquisa, foram enfrentados e transpostos. Desafios esses marcados pela extensão do estudo, por tratar-se de "um experimento de pesquisa participativa" (p.20) em consonância com a natureza do Fórum Nacional de Participação Popular, e de absorver registros de uma diversidade de experiências com diferentes formatos e nominadas de Orçamento Participativo. De um somatório de mais de 140 municípios mapeados, em processos que guardavam relação de proximidade ao Orçamento Participativo, a totalização dos dados recaiu sobre 103 questionários respondidos, informaçōes essas obtidas da administração municipal.

Firmando o desafio de desvendar as práticas sobre as quais se erguem o Orçamento Participativo, Ana Clara Ribeiro e Grazia de Grazia reúnem uma riqueza de informaçóes acumuladas das experiências e vivências levantadas, classificando-as, sistematizando-as, quantitativa e qualitativamente, para ensejar uma análise que permite indicar, com clareza, a ampliação das experiências, iniciadas e restritas às gestôes do PT, para uma adoção pelos mais diversos partidos políticos ou ainda resultante de alianças partidárias. Pensar em uma experiência que se amplia na territorialidade do país, abarcando uma diversidade de cidades com densidade demográfica desigual e importância político-econômica distintas; assumindo formatos institucionais múltiplos; e alternativas diferentes de organização, o estudo exigiu uma maior complexidade analítica, resultando em uma leitura cuidadosa, tão própria das autoras.

Há, na prática do Orçamento Participativo, elementos de uma nova cultura política em curso, assentada na perspectiva da transformação das relações governo versus sociedade para, assim, paulatinamente, criar e conformar avanços no âmbito das instituições e, por esse caminho, formatar espaços para a co-gestão dos recursos públicos. Mas, como indica o estudo, "o Orçamento Participativo, além de ser uma experiência inovadora e em rápida difusão é, também, uma experiência difícil e instável" (p.36). Instabilidade, em certos casos, decorrente das experiências terem início, sem, no entanto, perdurarem no decorrer da gestão na qual se originou. Além disso, com muita transparência a pesquisa demonstra que o Orçamento Participativo não se apóia em uma dinâmica única.

Relevante situar, nas páginas da pesquisa, a importância assumida pela mobilização social resultante do encadeamento do processo participativo associado às experiências de Orçamento Participativo. Todavia essa mobilização é, fortemente, capitaneada pela prefeitura, "mas a sua ocorrência efetiva depende sobretudo das formas de organização social e política existentes no município" (p.57). Isso implica, portanto, seguir os passos das associações representadas, apreen- 
der as formas de sua participação e da participação traduzida na presença às reuniōes e os vínculos com suas bases organizativas. Indagações a serem aprofundadas, além do âmbito dessa pesquisa.

$\mathrm{O}$ estudo mostra com bastante intensidade que $\mathrm{o}$ Orçamento Participativo encontra-se institucionalmente atrelado ao Gabinete do prefeito - segundo o estudo, aproximadamente a metade do conjunto dos municípios estudados apresenta essa configuração institucional. Nesse momento, parece ficar patente a relação de dependência da autoridade, indicando, por um lado, um estado de incerteza, de fragilidade, diante da conquista na iniciação de práticas participativas, e, por outro, sinalizando as disputas geradas em decorrência do processo participativo e as relações de poder gestadas nas entranhas da esfera governamental. Realidade sugestiva de longa caminhada para a remoção desses obstáculos.

As novas expressões de práticas democráticas suscitam a formulação de uma ampla gama de questóes, dentre as quais a relação democracia participativa e orçamento participativo. Ao leitor atento, inúmeras descobertas advirão do mergulho aprofundado no manusear cuidadoso dos dados disponíveis sobre as recente experiência de Orçamento Participativo.

As autoras - Ana Clara Torres Ribeiro, a quem o título de professora ressoa com bastante propriedade, pesquisadora e intelectual de envergadura; e Grazia de Grazia, mestra em Planejamento Urbano e Regional, pesquisadora e profissional de competência reconhecida -, imprimiram à análise das informaçôes um tom que reafirma seus compromissos éticos e profissionais com as lutas sociais e o empenho em subsidiar e fortalecer canais de participação popular, abertos e em franca caminhada no pós-Carta Magna de 1988.

Para realizar uma empreitada tão ampla, as autoras somaram esforços de um conjunto significativo de organizaçôes não-governamentais e de outras entidades comprometidas, por suas práticas, em dar suporte às mudanças em curso na sociedade e de acompanhar os diversos processos sociais a partir dos quais essas mudanças se delineiam. Essas organizaçōes compartilharam a responsabilidade pelo levantamento de informaçōes, junto aos municípios, e contribuíram em debates a respeito das novas situações desveladas.

Mas além do expresso, outra relevante contribuição faz-se presente pelos veios abertos com a pesquisa, apontando, assim, na direção de inúmeras possibilidades de fontes de conhecimentos a serem desvendadas, ampliando o leque de alternativas capazes de ensejar futuros estudos devido à premência em responder, freqüentemente, a novos desafios da realidade em curso. Outrossim, o conjunto de informações, articuladas na publicação da pesquisa, constitui fonte segura para refletir os meandros da prática do Orçamento Participativo, da qualidade da participação referente ao uso de recursos coletivos aos elementos que daí se depreendem para rever a ação político-administrativa e o alargamento da vivência democrática da sociedade. 